\title{
TYPES OF PLATFORM BASED COLLABORATIVE ECONOMY AND ITS POTENTIAL AREAS IN AGRIBUSINESS
}

\author{
András Nábrádi ${ }^{1}$, Tünde Zita Kovács²
}

\begin{abstract}
Platform Based Collaborative Economy (PBCE) is new social and economic systems that include exchange of human and physical resources through Internet platforms where access provision is transferred. In the last 10 years, many forms of the PBCE have emerged, but a definition, which is fundamental (for example to legislation), has not yet been made. In addition in agriculture, the phenomenon of "co-operation" is not new, but platform-based implementation however has not yet general. By analysing international literature and exploratory research, the categories of PBCE and demand side oriented economy model were systematized, and then, through examples, the categories of PBCE in agribusiness were analysed. The PBCE is a demand-driven business model based on the information technology platform. The economic activity created by digital marketplaces and technology companies - to meet consumer demands - takes place through the platform for immediate access to goods and services. On digital marketplace product or service information is provided by multiple third parties, whereas transactions are processed by the marketplace operator. Based on Internet data collection, the main areas of agricultural application of the PBCE were explored and presented with examples. The spread of new economic system within agriculture can be achieved in two main ways: by sharing assets and crowdfunding. Practical implications of this article that clearly defined the concept of PBCE, and its sub-areas, first - to our knowledge - the categories of crowdfunding. Also first, by presenting examples, the article summarized the field of agricultural application in the field of PBCE.
\end{abstract}

Key words: Collaborative economy, crowdfunding, agribusiness, online market, online content.

JEL $^{3}$ : D16, F12, L26

1 András Nábrádi, Ph.D., Full Professor, University of Debrecen, Böszörményi út no. 138, 4032 Debrecen, Hungary, Phone: +36 52508 444/ext. 86910, Email: nabradi.andras@econ.unideb.hu

2 Tünde Zita Kovács, Ph.D. Student, University of Debrecen, Böszörményi út no. 138, 4032 Debrecen, Hungary, Phone: +36 52508 444/ext. 86902, Email: kovacs.tunde.zita@econ.unideb.hu

3 Article info: Original Article, Received: $6^{\text {th }}$ February 2020, Accepted: $10^{\text {th }}$ June 2020. 


\section{Introduction}

The mass proliferation of Internet technology has opened up a new economic form: a platform-based, demand-driven, collaborative economy. Even the nomenclature is not uniform, and its formation can be measured only in decades, but its spread is at the speed of light. The European Commission published its Guideline on the Collaborative Economy (or Sharing Economy or Platform based Economy) in 2016, which it sees as an innovative business model that will serve the European Union's economic growth with the right promotion and the appropriate regulatory framework, and can greatly boost job creation (European Commission, 2016). However, regulation is still to come, and is essential to ensure investment security and risk management in a given country, and fewer people are excluded from economic activity and the country's production capacity increases (Wynhoven, Koulias, 2015). The basic requirement for rulemaking is a thorough knowledge of the field and a clear demarcation of the concepts involved. In the last 10 years, many forms of the Platform-based Economy have emerged, but a clear and exact definition, which is fundamental to legislation, has not yet been made. International literature is receptive to alternative denominations of the platform based sharing (collaborative) economy, which does not facilitate understanding of the phenomenon, as they are often overlapping and often arbitrarily exchanged (Martin, 2016). Adjacent notions recommends for use: collaborative consumption (Botsman, Rogers, 2010; Hamari et al., 2014), peer-to-peer based sharing (Schor, 2015), crowd-based capitalism (Sundararajan, 2016), gig economy (Friedman, 2014), renting economy, connected consumption (Schor, Fitzmaurice, 2015), access economy (Eckhardt, Fleura, 2015), on-demand economy (Cockayne, 2016; Selloni, 2017), gift-economy (Eisenstein, 2011), and finally "The sharing economy has become a catch-all label with strong normative underpinnings" (Acquier et al., 2017, old. 1). Each of these terms describes the same model, but focuses on different elements of the economy. Kovács and Nábrádi (2020) recorded two basic forms of platformbased economy: redistribution market and product-service system. Within this, the demand-side oriented categories they are clearly defined of Sharing Economy (SE) and Collaborative Consumption (CC), which can be found even in the agricultural sector. The SE is most appropriately explained by $\mathrm{P} 2 \mathrm{P}$ and $\mathrm{P} 2 \mathrm{~B}$ constructions and initiated through private individuals. On the contrary, $\mathrm{CC}$ is described as the exchange between $\mathrm{B} 2 \mathrm{P}$ and $\mathrm{B} 2 \mathrm{~B}$ players, but initiated by profit oriented organizations. The SE and the $\mathrm{CC}$ are two similar social and economic systems that both include exchange of human and physical resources through platforms where access provision is transferred (permanently or not permanently). The question arises as to what type of demanddriven, platform-based businesses can be identified in agriculture. The study attempts to answer this key question through examples. 


\section{Materials and Methods}

The first step was to define what is a demand-driven, platform-based business by comparing it with traditional "pipeline" type company. For many decades, businesses have been operating according to a well-defined scheme, known as the traditional or "pipeline" type, where value creation takes place along a linear series of activities called the classic value chain model. It achieves the value offered to the individual consumer by maximizing the efficiency of in-house processes while defending against the five forces that influence competitiveness, as identified by Porter (1979). In supply-driven economies, companies gain market power by controlling resources, relentlessly increasing efficiency, and eliminating the challenges of the five forces (van Alstyne et al., 2016). In contrast, for demand-driven, platformbased economies the resource is the community and their main asset is the network of producers and consumers. The platform connects manufacturers and consumers in a process called value creation. The platform is looking at how to maximize the value of an expanding ecosystem that is circular, repetitive and feedback driven. We can say that pipeline companies are supply side oriented, they operate along the value chain principle and are essentially marketing oriented, whereas PBCE type companies are mainly demand side oriented, with the use of the internet platform and at the same time the network building principle. For capacity-limited assets (physical assets, capital, and labour), indirect network effects occur, which means that the value of the service increases with a user group when a new user group joins the platform network (Johnson, 2018). Demand-driven platform-based businesses create value by enabling interaction between two or more customer, participating groups. Kovács and Nábrádi (2020) defined the categories under demand-side platforms, and identified the characteristics of CC and SE. Figure 1 shows what activities belong to the two groups. 
Figure 1. Classification of demand-side platforms

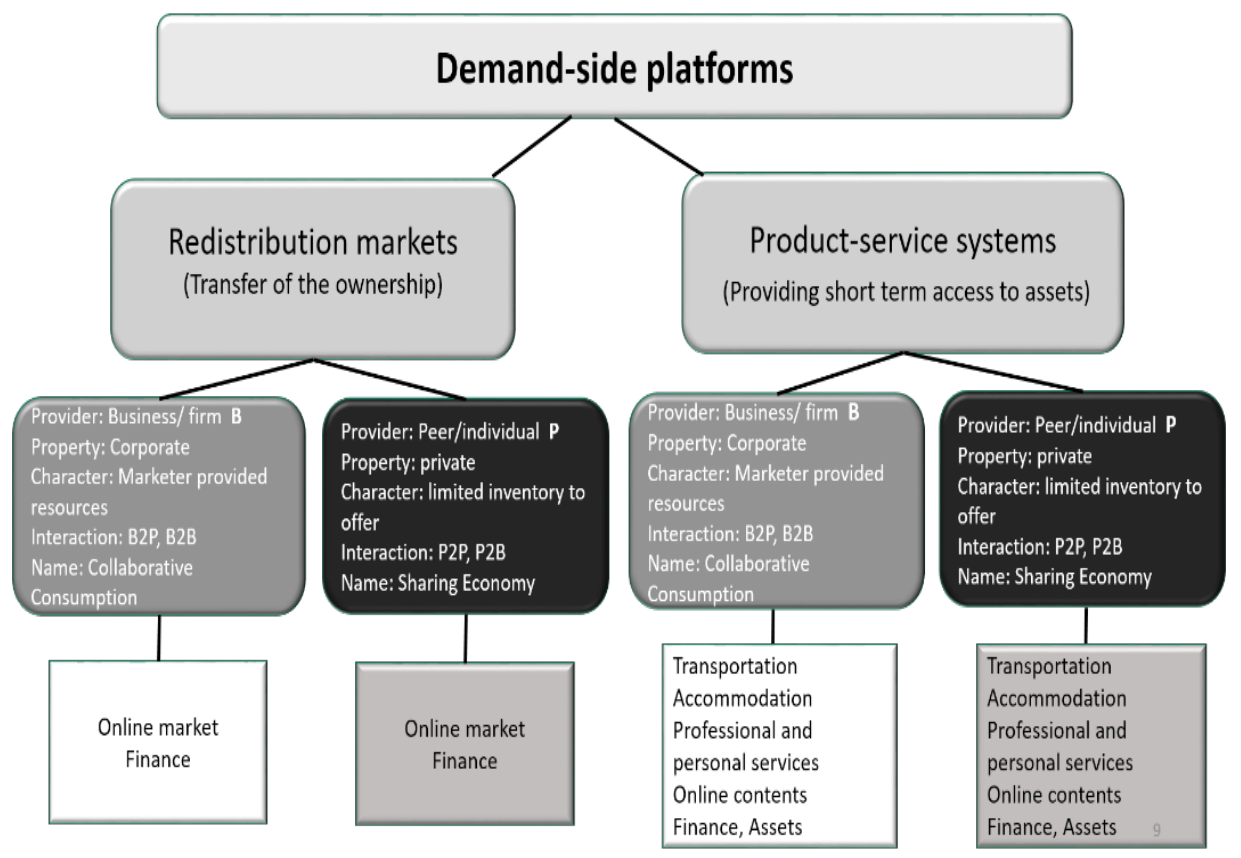

Source: Kovács, Nábrádi, 2020.

Through exploratory research in the crowdfunding area, a deeper analysis was conducted, resulting in the exploration of its subcategories.

With data and information mining we were looking for examples of $\mathrm{CC}$ and SE businesses in agriculture. By analysing the companies' websites, it was searched and filtered what demand-driven platform based examples can be used to support the spread of agriculture. Among the agricultural options, we have empirically mapped the currently useful versions of the possible Collaborative Economy. In our work, we conducted Internet-based research, collecting the websites of companies that most likely operate according to the definition was fixed.

In summary, the methods of analysis used are as follows:

1. We eliminated the overlaps using the International Literature, but at the same time using their optional elements, we enriched the field of science with a new, clear definition of PBCE.

2. To the best of our knowledge, no one has grouped this area in Crowdfunding. By processing international literature, and also applying the simple logical approach, we established categories free of overlaps were systematized. The system is suitable for differentiating the diverse areas of crowdfunding by industry and service. 
3. With data and information mining, we were collecting agricultural companies fulfil the requirement of definition of Collaborative Economy.

4. Finally, we combine the results of our previous research in our current article, where we analysed a survey "Flash Eurobarometer 467, "The Use of the Collaborative Economy" (European Commission, 2018), conducted in 28 EU Member States using the SPSS 25 statistical program where 26,544 survey basic and derived data were analysed and processed. Here, only a few final conclusions from the analysis are mentioned or highlighted.

\section{Results and Discussion}

1) Using the international literature, systematizing them and filtering out overlaps, we formulated (Kovács et al., 2020) than here in this article refined the definition of Platform Based Collaborative Economy (PBCE) as follows: The PBCE is a demand-driven business model based on the information technology (IT) platform. The economic activity created by digital marketplaces and technology companies - to meet consumer demands - takes place through the IT platform for immediate access to goods and services. On digital marketplace product or service information is provided by multiple third parties, whereas transactions are processed by the marketplace operator (Technology Company). The PBCE is applies not only selling/ renting new commodities, but also to selling/renting unused assets and reusing them via online marketplaces. The PBCE distinguishes between the concepts of Collaborative Consumption (CC) and Sharing Economy (SE).

2) Platform-based economy or collaboration has many things in common with traditional cooperatives. At the European Union level, the most cooperative countries are Italy, Greece, Germany, however, France (EUR 52.6 billion), Germany (EUR 39.3 billion) have the strongest agricultural cooperatives in terms of their business turnover (Bratulescu, 2017). Cooperatives present a unique opportunity to drive a collaborative economy with an emphasis on people's needs and community-driven innovation and this can be a cooperative renaissance in disguise (ICA, 2019). However, in the former socialist countries, the term collaboration is negatively charged because of the former "cooperative" system. For this reason, it should not be forgotten that any collaboration has been burdened with negative emotions for a long time to come. For example, the number of agricultural cooperatives in Hungary decreased from about 4,000 to 2,000. But it also underscores the importance of the declining willingness of those living in agriculture to cooperate. Whatever the cooperation, based on a completely new system, is almost impossible due to previous negative experiences. Perhaps any collaboration based on the Internet can unleash this negative emotion. Because it does not require personal (face to face) cooperation! 
In the case of the (2.1) online market, platform-based sales (seed, fertilizer, pesticide, machinery and machine parts) belonging to CC: seedsnow.com, Europe-agriculture. com, bartsparts.eu, CEMA, tangeragro.com, Oazis web shop, shoupparts.com, Nebelung $\mathrm{GmbH}$, etc. In these cases, the provider is always a business. If the ownership of the machines or equipment remains with the service provider, then we can speak either CC (Axial Co., KITE.Co.) or SE (HarvestPort, AgTribe) types of platform based economy. Benefits of using shared farm machinery and equipment are as follows: reduce capital investment in machinery and facilities; save on operating costs; take advantage of new technology; access specialized equipment; attain greater economy of scale at a lower financial cost; shared labour and experience; agreements that open new markets; additional savings though joint purchasing of other farm inputs such as fuel, feed, seeds, etc.; collaborative production systems among farmers to make better use of land resources, improve crop rotations and facilitate joint marketing and distribution (Basarik, Yildirim, 2015).

The (2.2) Online contents services can be a great help in precision farming, enabling farmers and cooperatives to produce more with less resources. Through data analysis, additional productivity gains can be achieved in agriculture (Copa, Cogeca, 2018).

The (2.3) Finance - Technology innovation is also having an impact on the provision of financial services, and disruptive technology has resulted in significant performance improvements at lower costs. Technology-driven financial innovation has become widely known as FinTech (Financial Technology), resulting in new applications, products and business models on the financial markets and new financial services. Today, financial services are not restricted to banking institutions. Lending on P2P or community basis offers the same as a banking institution, but at lower costs, at more favourable interest rates than a bank. Investors and fund seekers are linked by an Internet platform that is available 24 hours a day. This phenomenon is also called shadow banking (Mester, 2016). There is no legal background for community funding (crowdfunding), they are not subject to regulatory oversight, and they do not have to meet stringent requirements. Nonetheless, PwC (2015) predicts collaborative finance to grow from EUR 2 billion in 2015 in the European Union to EUR 200 billion in 2025. Belleflamme et al. (2015) distinguish between two major types of community funding platforms (hereinafter CFPs): investment-based and reward- and donation-based CFPs. Thinking further, and using its international publications, we made additional groupings. Investment-based CFPs can also be further broken down:

(1) equity-based financing where the entrepreneur offers equity ownership in exchange for financing. Ex.: CircleUp, SeedInvest, Tökeportál.hu, Multifinantare.ro. 
Figure 2. Classification of Crowdfunding Financial Platforms and the possible spread in the agricultural sector

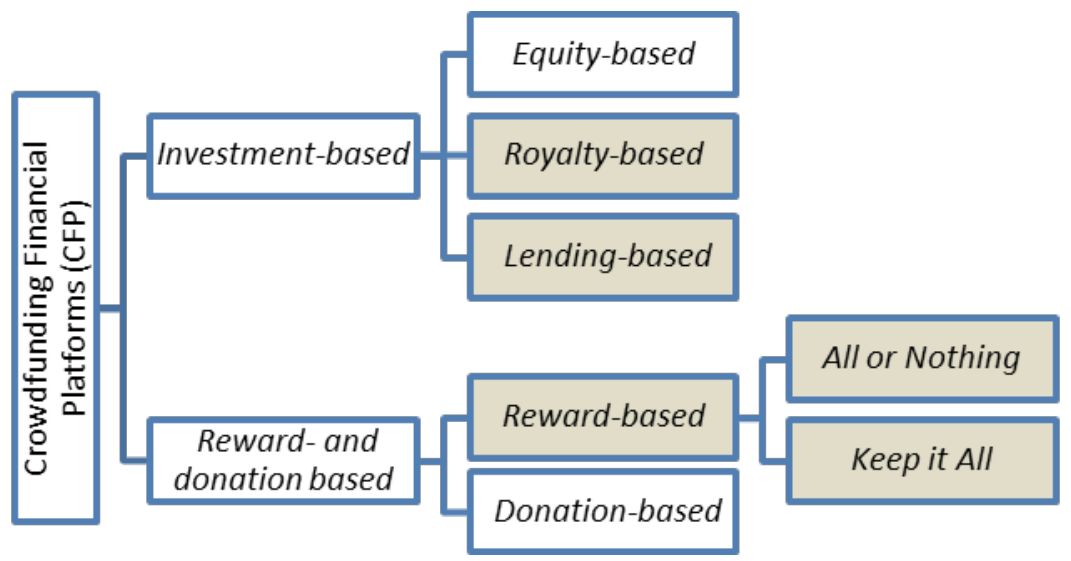

Source: According to author's opinion.

(2) royalty-based financing where the project owner offers a portion of future capital revenue generated to investors. Ex.: Quirky.

(3) lending-based financing, where community members lend to a person or business together. Ex: CircleUp, MagNetBank, Prosper, Zopa, Grupeer, FundingCircle, Lending Club.

In exchange for reward and donation-based financing, investors do not expect cash profits, in exchange for services, products, or simply support their realization, or perhaps a combination of the two. The reward- and donation-based CFP can also be further broken down: AON (All or Nothing) financing, the contractor predetermines the amount to be collected, which he receives only when it is collected, so when the limit is reached, the project starts. Ex.: Kickstarter, Crowdfunder, Crowdsupply, WeAreHere, Multifinantare.ro, Potsieu.ro, Startarium. KIA (Keep-It-All) financing, whether or not a predetermined source is raised, the amount can be used to carry out the project. Ex.: IndieGogo, GoFundMe, Sponsume.

3) In Figure 2. it was classified of Crowdfunding Financial Platforms as general, we highlighted the structure of crowdfunding and the possible spread in the agricultural sector as well. The figure highlighted in grey the forms of financing that were most likely to occur in the agribusiness area.

4) Author's previous research (Kovács et al., 2020; Nábrádi, Kovács, 2020) has shown that the collaborative economy is only just beginning to spread within the EU. According to a $2018 \mathrm{EU}$ survey, approx. 22\% of respondents use this platform to manage their business (Figure 3.). 
Figure 3. Proportion of users and providers of services offered through collaborative platforms within EU member states in 2018.

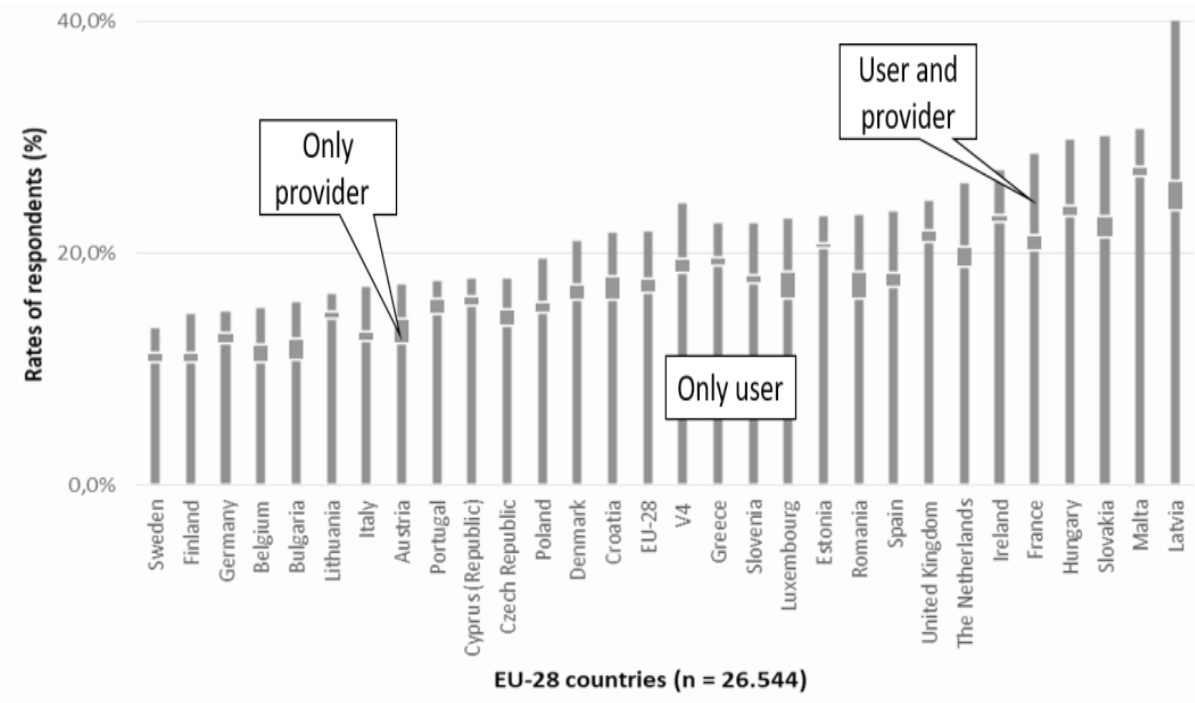

Source: According to author's opinion.

The proportion of users and providers is highest in Latvia, and relatively high in Hungary and Slovakia. It can also be seen in the Figure 3 that the average of the V4 countries is higher than the EU average. In any case, the proportion of users and providers is still quite low.

However, development is rapidly changing. COVID-19 in 2020 has also accelerated online connections. A lot of people are already running their businesses through the Internet platform. Peer to Peer and Business to Business connections cannot be constrained. In our global world, borders only formally exist, and business transactions are growing rapidly through the Internet. But, the analysis and investigation of all this will be the task of another scientific article.

\section{Conclusions}

In our work we defined the concept of Platform Based Collaborative Economy, its structure and composition. With this, we formed distinctly separable groups, which may also be suitable for different decisions.

We provided a complete picture of the areas of crowdfunding. To our knowledge, this has not appeared anywhere else. With this we can strengthen the field of science, but we have not dealt with its practical application yet. 
Among the agricultural options, we have empirically mapped the currently useful versions of the possible Collaborative Economy. We found that the use of this new method is currently widespread in two large groups and in three areas. In agricultural sector: as a result of the investigation, within the umbrella of demanddriven, Internet platform based economy there are: 1) online markets, 2) online contents, and 3) finance services consider in the agricultural sector. The spread of new economic system within agribusiness can be achieved in two main ways: by sharing assets and crowdfunding. In the agricultural sector, platform-based markets are predominantly CC-type. However, in the former socialist countries, the term collaboration is negatively charged because of the former "cooperative" system. As a result, in the current situation, its distribution is confronted with a generation constraint. However, according to the forecast of (PwC, 2015), the financing sector of the demand-driven, platform-based business is one of the most dynamically developing, by 2025 it may reach $36 \%$ of the financial transactions of the new type of economy.

Based on our previous surveys and research analyses, we found that Collaborative Economy is not yet widespread in the EU member states, but we also predicted that this new economic formation will have no borders, facing exponential growth. Because of all this, deeper research on the topic is not just an opportunity but a necessity!

\section{References}

1. Acquier, A., Daudigeos, T., Pinkse, J. (2017). Promises and paradoxes of the sharing economy: An organizing framework. Technological Forecasting and Social Change, 125:1-10, doi: 10.1016/j.techfore.2017.07.006

2. Bașarik, A., Yildirim, S. (2015). A Case Study of Sharing Farm Machinery in Turkey. International Journal of Natural and Engineering Sciences, 9(3):1-5.

3. Belleflamme, P., Omrani, N., Peitz, M. (2015). The economics of crowdfunding platforms. Information Economics and Policy, 33(2015):11-28.

4. Botsman, R., Rogers, R. (2010). What's Mine Is Yours: The Rise of Collaborative Consumption. Harper Business, NY, USA.

5. Bratulescu, A. M. (2017). Agricultural cooperatives in developing agriculture in Romania and the European Union. In: Ursu, A. (edt.) Agrarian Economy and Rural Development - Realities and Perspectives for Romania, ICEADR, Bucharest, Romania, 8:285-289.

6. Cockayne, D. (2016). Sharing and neoliberal discourse: The economic function of sharing in the digital on-demand economy. Geoforum, 77:73-82, doi:10.1016/j. geoforum.2016.10.005 
7. Copa-Cogeca (2018). New Code of Conduct on agricultural data sharing launched to move into digital age. Magazine: EU Farmers \& Agri-Cooperatives, Copa-Cogeca, Bruxelles, Belgium, 19:3-4.

8. Eckhardt, G. M., Fleura, B. (2015). The Sharing Economy isn't about Sharing at all. Harvard Business Review, retrieved at: https://hbr.org/2015/01/the-sharingeconomy-isnt-about-sharing-at-all, $3^{\text {rd }}$ December 2019.

9. Eisenstein, C. (2011). Sacred Economics. Evolver Editions, Berkley, CA, USA.

10. European Commission (2016). A European agenda for the collaborative economy. European Commission, Brussels, Belgium, retrieved at: https://eurlex.europa.eu/legal-content/EN/TXT/?uri=COM $\% 3 \mathrm{~A} 2016 \% 3 \mathrm{~A} 356 \% 3 \mathrm{AFIN}$, $4^{\text {th }}$ December 2019.

11. European Commission (2018). Flash Eurobarometer 467 (The Use of Collaborative Economy). GESIS Data Archive, Cologne. Brussels Belgium, TNS opinion, doi: https://doi.org/10.4232/1.13159

12. Friedman, G. (2014). Workers without employers: shadow corporations and the rise of the gig economy. Review of Keynesian Economic, 2(2):171-188, doi:10.4337/roke.2014.02.03.

13. Hamari, J., Sjöklint, M., Ukkonen, A. (2014). The Sharing Economy: Why People Participate in Collaborative Consumption. Journal of the Association for information science and technology, 67(9):2047-2059, doi: 10.1002/asi.23552

14. ICA (2019). Cooperatives Europe Annual Report. International Co-operative Alliance (ICA), Cooperative House Europe, Bruxelles, retrieved at:https:// coopseurope.coop/sites/default/files/190517 COOPERATIVES\%20 EUROPE\%20ANNUAL\%20REPORT\%202.pdf, $11^{\text {th }}$ November 2019.

15. Johnson, N. (2018). What are Network Effects?, retrieved at: www.applicoinc. com/blog/network-effects/, $10^{\text {th }}$ October 2019.

16. Kovács, T., Nábrádi, A. (2020). Types of sharing economies and collaborative consumptions. In: Druzic, G., Gelo, T. (eds.) Conference Proceedings of the International Conference on the Economics of Decoupling (ICED), Faculty of Economics \& Business, University of Zagreb, Croatia, pp. 530-546, retrieved at: https://drive.google.com/file/d/1DdshSw72OTlLWr6MdjEtBZNbkMf9RcII/ view

17. Kovács, T., David, F., Kovács, K., Popovics, P., Nábrádi, A. (2020). Collaborative Economy and its Awareness in Visegrad Group Countries and within the European Union. Issues in Information Systems, 21(1):153-166.

18. Martin, C. (2016). The sharing economy: A pathway to sustainability or a nightmarish form of neoliberal capitalism? Ecological Economics, 121:149-159, doi:10.1016/j.ecolecon.2015.11.027 
19. Mester, É. (2016). A bankok versenyképessége. In: Gyenge, B., Kozma, T., Tóth, R. (eds.), Folyamatmenedzsment kihívásai - Versenyképességi tényezők a 21. Században, pp. 191-206, Gödöllö: Szent István Egyetem Gazdaság-és Társadalomtudományi Kar, Hungary.

20. Nábrádi, A., Kovács, T. (2020). Sharing Economy and its Popularity in Hungary and Romania. Oradea Journal of Business and Economy, 5(1):60-71.

21. Porter, M. (1979). How Competitive Forces Shape Strategy. Harvard Business Review, 57(2):137-145.

22. PwC (2015). Sharing or paring? Growth of the sharing economy. Price Waterhouse Coopers Magyarország Kft (PwC), Budapest, Hungary, retrieved at: $\quad$ www.pwc.com/hu/en/kiadvanyok/assets/pdf/sharing-economy-en.pdf, $5^{\text {th }}$ March 2020.

23. Schor, J. B. (2015). Getting Sharing Right. Contexts, 14(1):14-15, doi: $10.1177 / 1536504214567860$

24. Schor, J., Fitzmaurice, C. (2015). Collaborating and Connecting: The emergence of the sharing economy. In: L. Reisch, J. Thogersen (Eds.), Handbook of Research on Sustainable Consumption, p. 480, Edward Elgar, Cheltenham, UK, doi: $10.4337 / 9781783471270$

25. Selloni, D. (2017). New Forms of Economies: Sharing Economy, Collaborative Consumption, Peer-to-Peer Economy. In: CoDesign for Public-Interest Services. Research for Development, Springer, Cham, Switzerland, pp. 15-26, doi:10.1007/978-3-319-53243-1_2

26. Sundararajan, A. (2016). The Sharing Economy: The End of Employment and the Rise of Crowd-Base Capitalism. MIT Press, London, UK.

27. van Alstyne, M., Parker, G., Choudary, S. (2016). Pipeline, platforms, and the new rules of strategy. Harvard Business Review, 94(4):54-62.

28. Wynhoven, U., Koulias, C. (2015). Business for the rule of law framework. UN Global Impact, NY, USA, retrieved at: https://d306pr3pise04h.cloudfront. net/docs/issues doc\%2Frule of law\%2FB4ROL Framework.pdf, $\quad 29^{\text {th }}$ October 2019. 
